\title{
Correction to: Screening of pectinase-producing bacteria from citrus peel and characterization of a recombinant pectate lyase with applied potential
}

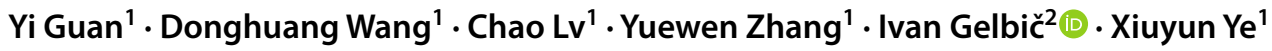

Published online: 15 May 2020

(c) Springer-Verlag GmbH Germany, part of Springer Nature 2020

\section{Correction to: Archives of Microbiology \\ https://doi.org/10.1007/s00203-020-01807-0}

In the original article, the article title has been published incorrectly. The correct article title is "Screening of pectinase-producing bacteria from citrus peel and characterization of a recombinant pectate lyase with applied potential.

Publisher's Note Springer Nature remains neutral with regard to jurisdictional claims in published maps and institutional affiliations.

The original article can be found online at https://doi.org/10.1007/ s00203-020-01807-0.

Ivan Gelbič

gelbic@entu.cas.cz

$\triangle$ Xiuyun Ye

xiuyunye@fzu.edu.cn

1 Fujian Key Laboratory of Marine Enzyme

Engineering, Fuzhou University, Fuzhou 350116,

People's Republic of China

2 Biology Centre Czech Academy of Sciences, Institute of Entomology, Branišovská 31, 37005 Česke Budějovice,

Czech Republic 